\title{
THE TRANSFER OF SLOBODAN MILOSEVIC TO THE INTERNATIONAL CRIMINAL TRIBUNAL FOR THE FORMER YUGOSLAVIA (THE ICTY) AND THE TURNING POINT IN INTERNATIONAL HUMANITARIAN LAW
}

\author{
Yard. Dof. Dr. Yusuf AKSAR*
}

\section{Introduction}

The international community has witnessed many human rights violations which have also constituted violations of international humanitarian law throughout the twentieth century. As of the end of World War II, the number of conflicts of an international nature declined and the number of internal conflicts has increased. In compliance with this fact, internal conflicts and tyrannical regimes made millions of people the victims of unimaginable atrocities that deeply shock the conscience of humanity. From World War II through 1996, the number of people killed reached as many as 86 million people in 220 non-international armed conflicts, including the acts of tyrannical regimes as well.' Until the last decade of the twentieth century, there have been only few prosecutions of responsible persons either at the international or national level and the practice of impunity was common to bring an end to the ongoing conflicts. ${ }^{2}$ In the last decade of the twentieth century, the large scale of killings, rape and other forms of sexual violence, "ethnic cleansing", genocide and other types of crimes committed in the territories of the former Yugoslavia and in Rwanda impelled the international community to bring those responsible of such

*Yusuf Aksar, LL.B. Ankara University Law Faculty, LL.M. Ankara University Law Faculty, LL.M. Sheffield University Law Faculty. Ph.D. Bristol University Law Faculty. Assistant Professor of Public International Law at the Department of International Relations, Karadeniz. Technical University Faculty of Economics and Administrative Sciences. TrabzonTurkey.

'Jоуnет. С. C. "Redressing Impunity for Human Rights Violations: The Universal Declaration and the Search for Accountability", (1998) 26 Dem. J. In'l L. \& Pol'y p. 593. For a detailed work in this sense. see Rummel, R. J. Death by Government, (1994).

${ }^{2}$ Bassiouni, M.C. "Searching for Peace and Achieving Justice: The Need for Accountability". (1996) 59 LCP pp. 11-12. 
crimes to justice. On this ground, the UN Security Council establistred "the International Criminal Tribunal for the Prosecution of Persons Responsible for Serious Violations of International Humanitarian Law Committed in the Territory of the Former Yugoslavia since 1991" (hereinafter the International Criminal Tribunal for the Former Yugoslavia: the ICTY) ${ }^{3}$ and "the International Criminal Tribunal for the Prosecution of Persons Responsible for the Serious Violations of International Humanitarian Law Committed in the Territory of Rwanda and Rwandan Citizens Responsible for Genocide and Other Such Violations Committed in the Territory of Neighbouring States, between 1 January and 31 December 1994" (hereinafter the Intermational Criminal Tribunal for Rwanda: the ICTR) ${ }^{4}$ acting under Chapter VII of the UN Charter in 1993 and in 1994 respectively.

The establishment of the ICTY and the ICTR was innovative in character since being established by the Security Council on behalf of the entire international community. This development also paved the way for the establishment of the International Criminal Court (the ICC) in 1998. In accordance with these developments, it should be noted that "[i]nternational humanitarian law has developed faster since the beginning of the atrocities in the former Yugoslavia than in the fourand-a-half decades since the Nuremberg Tribunals and the atoption of the Geneva Conventions for the Protection of Victims of War of August $12,1949^{*}$.

The enforcement of the rules of international humanitarian law through either ad hoc tribunals or an international criminal court is quite different and also difficult from the practice of national criminal courts. There are no

"Adopted unanimously by the Security Council at its 3217 meeting. on 25 May 1993. SC. Res. 827. U.N.SCOR. 48th Year. 1993 SC. Res \& Dec. At 29. U.N.Dot. S/INF/49 (1993). For the establishment and its legal basis, see Odman. T., "Eski Yugoslavya Ille İlgili Uluslararass Cexa Mahkencsinin Kuruluşu ve Yasal Dayanağ $131-151$

${ }^{+}$Adopted by a vote 13-1-1 by the Security Council at its 3453 rd meering. on 8 November 1994. SC. Res, 955. U.N.SCOR. 49th Year, 3453 mecting at 1, U.N.Doc. S/Res/955 (1994).

${ }^{5}$ Rome Statute of the International Criminal Court, adopted by the United Nations Diplomatic Conference of Plenipotentiaries on the Establishment of an International Criminal Court on 17 July 1998. U.N.Doc. A/CONF 183/9. The ICC Statute is available on the net: www un orv/icc/. For the establishment of the ICC see Aksar. Y. The Ad Hor Triburals and International Huntumarian Law, (Ph.D. thesis. Bristol University Law Faculty). 2000. Ch. 2. pp. 49-79.; Alibaba. A.. "Uluslararası Ceza Mahkemesinin Kuruluşu". (2006) 44/-4 A Pp. $181-207$.

"Meron. T.. "War Crimes Law Comes of Age", in Thedor Meron, War Crmes Law" Comes of Ase. Esistix, Oxford: Clarendon Press, (1998), p. 297. 
judiciary. legislature and executive organs in international law as we know from domestic legal systems, which are also too different from one nation to other. For this reason, the rules of international law need to be interpreted and applied at the international level, that may have different meaning from the domestic law practice, by international judicial institutions. One of the best examples of this fact can be found in the concept of "extradition". Is the term "extradition" a correct one to explain the handing of a suspicious person who committed international crimes to an ad hoc tribunal or to an international criminal court? Or should it be named as "transfer" or "surrender" to international criminal tribunals or courts? This concept has also became so significant since the arrest of Slobodan Milosevic, former President of the Federal Republic of Yugoslavia, on 1 April 2001 and then the handing over of him to the ICTY on 28 June 2001.

The aim of this paper is to examine the legality of the transfer of Slobodan Milosevic to the International Criminal Tribunal for the Former Yugoslavia from the point of view of the principles of international humanitarian law. For this reason, the concept of individual criminal responsibility in international criminal law, in particular, the criminal responsibility of Head of States or Government or government senior officials will be briefly explained. Secondly, the reasons why Slobodan Milosevic had to be handed over to the ICTY and its significance in international humanitarian law will be indicated. Lastly, the concept of extradition and its differences from the terms "transfer or surrender" will be discussed.

\section{Individual Criminal Responsibility in International Law $^{7}$}

The concept of attribution of criminal responsibility to individuals is not a completely new issue in international law. Some international crimes such as piracy, slavery (slave trading and slave trafficking) were regulated in 1800 's and these regulations today became a part of customary international law, jus cogens (peremptory norms) in nature. ${ }^{8}$ For the first time at the international level, the enforcement of individual criminal responsibility under a treaty was provided in the Treaty of Versailles signed by Germany on 26 June 1919 that established the individual criminal responsibility of the ex-German emperor, Kaiser Wilhelm II, under Article 227 of that Treaty for

\footnotetext{
${ }^{7}$ For a detailed explanation on the concept of individual criminal responsibility and the practice of the ad hoc tribunals and their contribution to international humanitarian law and possible impact on the ICC in this regard. see Aksar. Ch. 3. pp. 79-I27.

${ }^{k}$ Bassiouni. M.. C.. Crimes Against Humaning in International Hananitarian Lau. Dordrecht, Boston. London: Martinus Nijhoff Publishers. (1992), pp. 193-196.
} 
the supreme oftence against peace. Article 228 provided the prosecution of German military personnel who committed war crimes."

However, the turning point for the development of the principal of individual criminal responsibility was the view taken by the international community to establish the International Military Tribunals at Nuremberg and at Tokyo in order to enforce personal responsibility for war crimes, crimes against peace and crimes against humanity after the Second World War. ${ }^{(t)}$ The practice of these tribunals clearly indicated that any individual,

"Article 228 of the Treaty of Versailles states: "The German Government recognises the right of the Alicd and Associated Powers to bring before militaty tribunals persons accused of having committed acts in violations of the laws and customs of war". The full text of the Treaty of Versailles is available on the net in the following address: http:/history acusd edu/gen/text/versaillestreaty/vercontents.html.

"So' Agreement for the Prosecution and Ptnishment of Major War Criminals of the Europeat Axis. 8 August 1945 (the London Agreement), 59 Stat. 1544. 82 U.N.T.S. 279 that includes the Charter of the Nuremberg Tribunal and the basic principles of the trial. However. the Tokyo Tribunal was not established by conclusion of a treaty. See Speciat Proctemation by the Supreme Commander for the Altied Powers, Establishment of an lmarmationat Tribund fer the far East, 19 January 1946. T.I.A.S. No. 1589. 4 Bevans 20.

Article 6 of the Charter of the International Military Tribunal (Nurembere) defincs war crimes. crimes against humanity and crimes against peace as follows:

“(a) CRIMES AGAINST PEACE: mamely, plamning, preparation. initiation or wagning of a war of atgression, or a war in violation of international treaties agrecments or assurances, or participation in a Common Plan or Conspiracy for the accomplishment of any of the loregoing:

(b) WAR CRIMES: namely, violations of the laws or customs of war. Such violations shall include, thu not be limited to. murder, ill-treatment or deportation to slave labour or for any other purpose of civilian population of or in occupied territory, murder or ill-treatment of prisoners af war or persons on the seats, killing of hostages, plunder of public or private property, wanton destruction of cities, towns, or villages, or devastation not justilied by military necessity:

(c) CRIMES AGAINST HUMANITY; namely. murder, extermination. enslavement. deportation. and other isluman aets committed against any civilian population, before or durinit the war. or persecutions on political, racial, or religious grounds in execution of or in connection with any crime within the jurisdiction of the Tribunal. whether or not in violation of domestic litw of the country where perpetrated.

Leaders, organisers, instigators, and accomplices participating in the formulation or execution of a Common Plan or Conspiracy to commit any of the foregoing crimes are responsible for all acts performed by any persons in execution of such plan."

One of the major results of the Second World War was the birth of the concept al genocide. Which is defined in Article 2 of the Genocide Convention as follows

"Genocide means any of the following acts committed with intent to destroy, in whole or in part, a national, cthnical, racial or religious group, as such:

(a) killing members of the group;

(b) causing serious bodily or mental harm to members of the group:

(c) deliberately jullicting on the group conditions of life calculated to bring about its physical destruction in whole or in part;

(d) imposing measures intended to prevent births within the group:

4. - 4+1 
regardless of his rank should be responsible for war crimes, crimes against peace and crimes against humanity and that individual responsibility is enforceable at the international level. ${ }^{1}$ Under this guideline, the ICTY, the ICTR and the ICC were able to be established by the international community. In particular, the latest developments left no room to discuss the possibility of the enforcement of individual criminal responsibility for the crimes which are all concern to the international community; war crimes, the crime of genocide, crimes against humanity and the crime of aggression all of which became independent category of international crimes that have reached the level of jus cogens (peremptory norms)and States' duty to prosecute, punish or extradite individuals responsible for these crimes, in other words, the enforcement of individual criminal responsibility in this respect became an obligatio erga onnes (literally obligations that "apply to all") in nature. ${ }^{12}$

(e) forcibly transferring clildren of the group to another group."

The mentioned crimes have also taken their places in international humanitarian law documents: In this context, for the concept of war crimes, see the four Conventions were signed at Geneva on 12 August 1949: Convention for the Amelioration of the Condition of Wounded and Sick in Armed Forces in the Field, 75 U.N.T.S. 31 (First Geneva Convention),; Convention for the Amclioration of the Condition of Wounded. Sick and Shipwrecked Members of Armed Forces at Sea, 75 U.N.T.S. 85 (Second Geneva Convention).: Convention Relative to the Treatment of Prisoners of War. 75 U.N.T.S. 135 (Third Geneva Convention): Convention Relative to the Protection of Civilian Persons in Time of War. 75 U.N.T.S. 287 (Fourth Geneva Convention).: Protocol Additional to the Geneva Conventions of 12 August 1949, and Relating to the Protection of Victims of International Armed Conflicts (8 June 1977) (Protocol I). (1977) 16 ILM 1391.: Protocol Additional to the Geneva Conventions of 12 August 1949, and Relating to the Protection of Victims of NonInternational Amed Conflicts (Protocol II). (8 June 1977). (1977) 16 ILM 1442.: Regulations Respecting the Laws and Customs of War on Land annexed to the Hague Convention No. IV Respecting the Laws and Customs of War on Land, (18 October 1907) in Schindler. D.. and Toman. J., (eds.) The Laws of Armed Conflicts A Collection of Conventions, Resolutions and Other Documents, (Sijthofl \& Noordoff: 1981), pp. 69-87.: Articles 2-3 of the JCTY Statute.; Article 8 (2) (a) (b) of the ICC Statute.; For the concept of crimes against humanity. see Article 5 of the Charter of the Tokyo Tribunal.; Article 5 of the ICTY Statute.; Article 3 of the ICTR Statute.; Article 7 of the ICC Statute.; For the crime of genocide, see The Genocide Convention, 78 U.N.T.S. 277 opened for signature on 8 December 1948 and entered into force on 12 January 1951.; Articles 2 and 4 of the ICTR and the ICTY Statutes respectively.; Article 6 of the ICC Statute. For the concept of crimes against peace, see Article 5 of the ICC Statute. For a detailed explanation on the mentioned crimes and the practice of the ad hoc tribunais in this regard, see Aksar, pp. 128-229, 275-303.

Ratner, S., R., and Abrams. J., S., Accountability for Human Rights Atrocitics in Inernational Law Beyond the Nuremberg Legacy, Oxford: Clarendon Press, (1997). p. 6.

"Final Report of the Commission of Experts Established Pursiant to Security Councit Resolution 935 (1994), para. 171.; Marquardt, P.. D.. "Law Without Borders: The Constitutionality of an Intemational Criminal Court", (1995) 33 Col. J. Trans.' / L. pp. 82-83.

${ }^{12 B a s s i o u n i . ~ M ., ~ C . . ~ " I n t e r n a t i o n a l ~ C r i m e s: ~ J u s ~ C o g e n s ~ a n d ~ O b l i g a t i o ~ E r g a ~ O m n e s " . ~}$ (1996) 59 LCP pp. 68, 72.: Sunga. L., S.. Individual Responsibility in International Law for Serions Howan Rights Violations. Dordrecht, Boston. London: Martinus Nijhoff Publishers. 
When the latest international humanitarian law instruments are examined the principle of individual criminal responsibility and its scope and content can be indicated as follows: First of all. Articles $7(1)$ of the ICTY and $6(1)$ of the ICTR Statutes ${ }^{13}$ states that: "A person who planned. instigated, ordered, committed or otherwise aided and abetted in the planning, preparation or execution of a crime referred to in articles 2 to 5 Article 2: War crimes, Grave Breaches of the Geneva Conventions of 1949, Article 3: Violations of the laws or customs of war, Article 4: Genocide. Article 5: Crimes against humanity] of the present Statute, shall be individually responsible for the crime". In the same vein, Article 25 of the ICC Statute sets out the basic principles of individual criminal responsibility in detail. ${ }^{5+}$ At first glance, it can be seen that these Articles reflect a broad approach to the occasions in which an individual can be held criminally responsible for his/her participation in the commission of an offence. The purpose of this type of regulation is to ensure that all those who take part in

(1992). pp. 52-53. 73.: Morris, M.. H.. "International Guidelines Against Impunity: Fatilitating Accountability". (1996) 59 LCP p. 29.

"The IC"SY and the ICTR Statutes ate available on the net: w'w un mordicty and wwictrorg.

${ }^{1+}$ Article 25 of the ICC Statute provides that

"1. The Court shall have jurisdiction over natural persons pursuant to this Stallute.

2. A person who commits a crime within the jurisdiction of the Court shall bo individually responsible and liable for punishment in accordance with this Statute.

3. In iccordance with this Statute, a person shall be criminally responsible and liable for punishment for at crime within the jurisdiction of the Court if that person:

(a) Commits suith a crime, whether as an individual, jointly with inother or through another person, regardless of whether that other person is criminally responsible:

(b) Orders. solicits or induces the comntission of such a crime which in latct oceurs or is attempled:

(c) For the purpose of facilitating the commission of such a critne. aids, abeth or otherwise assists in its commission or its attempted commission. including providing the means for its commission;

(d) In any other way contributes to the commission or attempted commission of such a crime by a group of persons acting with a common purpose. Such contribution shall bi intentional and shall either:

(i) Be made with the aim of furthering the criminal activity or criminal purpose of the group, where such activity or purpose involves the commission of a crime within the jurisdiction of the Court; or

(ii) $\mathrm{Bc}$ made in the knowledge of the intention of the group to commit the crimse; genocide:

(e) In respect of the crime of genocide, directly and publicly incites others to commit

(f) Atcempts to commit such a crime by taking action that commences its execution by means of a substantial step. but the crime does not occur because of circumstances independent of the person's intentions. However. a person who abandons the clitort to commir the crime or otherwise prevents the completion of the erime shatl not be liable for punsshment under this Statute for the attempt to commit that critne if that person completely and voluntarily gave up the criminal purpose". 
the planning, preparation or execution of serious violations of international humanitarian law, in other words, all those who contribute to the commission of the violation are individually responsible. ${ }^{15}$ More clearly, under Articles 7 (1) and 6 (1) of the ICTY and the ICTR Statutes, the principle of individual criminal responsibility is not only just for the persons who directly committed the crime (as principal), but also for the persons who facilitated the commission of the offence in a way indicated in the mentioned Articles (as participant).

The other significant provisions of the latest international humanitarian law instruments in relation to the concept of individual criminal responsibility explicitly indicates the responsibility of Head of States or other government senior officials. Articles 7 (2) of the ICTY and 6(2) of the ICTR Statutes provide that: "The official position of any accused person, whether as Head of State or Government or as a responsible Government official, shall not relieve such person of criminal responsibility nor mitigate punishment". Similarly, Article 27 of the ICC Statute consists of provisions which indicate that it will be applied equally to all persons without any distinction based on official capacity. ${ }^{16}$ The aim of the inclusion of these provisions in the Statutes of the ad hoc tribunals and of the ICC is to ensure the individual criminal responsibility for the persons who acted in pursuance of the authority of the State and to prevent them from using their official position as a defence not to be held criminally culpable. ${ }^{17}$ The enforcement of individual criminal responsibility for State officials either as Head of State or Government or government senior officials and non-recognition of the concept of sovereign immunity and its consequence impunity as a

is Report of the Secretary-General Pursutut to Paragraph 2 of Securing Council Resolution 808 (1993).Including the Draft Stamte of the Tribunal, (hereinatter SecretaryGeneral's Report),U.N.Doc. S/25704, 3 May 1993, para, 54,; Morris, V.. and Scharf. M., P.. An Insider's Guide to the Itternational Criminal Tribunal for the Former Yugoslavia, Vol. I. Irvington-on-Hudson, New York: Transnational Publishers. (1995), p. 93.. Morris. V.. and Scharf. M., P., The International Criminal Tribunal for Rwatda. Vol. I. Irvington-on-Hudson, New York: Transnational Publishers, (1998), p.233.

16 Article 27 of the ICC Statute, under the title of "irrelevance of offictal capacity" states:

"1. This Statuce shall apply equally to all persons without any distinction based on official capacity. In particular, official capacity as a Head of State or Government, a member of a Government or parliament, an elected representative or a government official shall in no case exempt a person from criminal responsibility under this Statute, nor shall it, in and of itself, constitute a ground for reduction of sentence.

2. Immunities or special procedural rules which may attach to the official capacity of a person. whether under national or international law, shall not bar the Court from exercising its jurisdiction over stuch a person."

17 "The Statute should ... contain provisions which specify that a plea of Head of State immunity or that an act was committed in the oflicial capacity of the accused will not constitute a defence, nor will it mitigate punishment". (Sccretury-General's Repont, para. 55). 
defence have significant place in international law in terms of implementing the principles of international humanitarian law. This is because, if the notion of sovereign immunity had been considered as a defence for example Head of Statc had enjoyed sovereign immunity, other officials (mititary or civilian) who are in lesser rank conld have claimed that they acted in accordance with superior orders, ${ }^{18}$ in consequence, there would not have been possibte to enforce international humanitarian and crininal law. In addition to the non-recognition of sovereign immunity as a defence not to be held criminally' accountable, even a mitigating factor, the position held in the level of a State or Government administration can (must) create an aggravating lactor in punishment on the ground that these officials are responsible for the maintenance of peace and security and their participation in a crime constitute abusing the authority or trust which they have just because of their official positions.

\section{The Reasons Why Slobodan Milosevic Must Be Handed over to the ICTY}

One of the main reasons to hand over Slobodan Milosevic to the International Criminal Tribunal at the Hague is the concept of individual criminal responsibility of persons who committed or facilitated the commission of an international crime which are all concern to the international community. These crimes include; war crimes, the crime of genocide crimes against humanity and the crime of aggression. As have been indicated above, there cannot be any doubt that atl aforementioned crimes have reached the level of jus cogens (peremptory norms) and States' obligation on prosecuting. punishing or extraditing the perpetrators of them, in other words, enforcing individual criminal responsibility is an obligatio erga ommes (literally obligations that "apply to all") in nature. The

"Acting in accordance with a superior order does not relicve the person in question fron criminal responsibility. In this context. Articles 7 (4) and 6 (4) of the Statutes of the ICTY and the ICTR provide that: "The fact that an accused person acted pursuant to an order of a Govetnment or of a superior shall not relieve him of criminal responsibility, but may be considered in mitigation of punishment if the Intemational Tribunal determines that justice so requires". Article 33 of the ICC Statute, under the title of "superior orders and prescription of law. stattes that:

"I. The lact that a crime within the jurisdiction of the Court has been commited by a person pursuant to an order of a Government or of a superior. whether military or civilian. shall not relieve that person of criminal responsibility unless:

(a) The person was under a legal obligation to obcy orders of the Government or the supcrior in question.

(b) The perion did not know that the order was uniaw ful; and

(c) The order wals not manifestly unlawful.

2. For the purposes of this article orders to commit genocide or ctimes against humathity atce manifestly unlatwful". 
international community promoted widespread adoption of the principle of universal jurisdiction for bringing indicted persons by international crimes to justice. According to the principle of universal jurisdiction, any State can prosecute an offender regardless of his/her nationality or of where the crime committed. ${ }^{19}$ As have been mentioned above, the official position of an offender as Head of State or Government or government senior officials does not relieve of him from prosecution. When these principles are applied to the Yugoslavian Case it can clearly be noticed that Slobodan Milosevic and other high ranking officials of the Federal Republic of Yugoslavia (Serbia and Montenegro) are individually and in concert with others planned, instigated, ordered or otherwise aided, abetted in the planning, preparation or execution of mass rape and sexual assault, of the unlawful detention of civilians, of unlawful attacks against the civilian population and individual civilians with area fire weapons such as mortars, rockets and artillery, of destruction of sacred sites, of persecution on political and religious grounds etc. responsible on the ground that all these crimes were committed as a part of ethnic cleansing that was planned, instigated and ordered by mainly political authorities in international law.

Secondly, the Dayton Peace Agreement ${ }^{21}$ was signed by the representatives of the Republic of Bosnia-Herzegovina, the Republic of Croatia and the Republic of Yugoslavia at the Paris Conference on 14 December 1995. The Dayton Peace Agreement accepted the ICTY as an "essential aspect" of peace implementation..$^{22}$ It is also important to note that the ratification of the Agreement by the Federal Republic of Yugoslavia was its first official recognition of the ICTY. ${ }^{23}$

Thirdly, the ICTY was established and its Statute was adopted by a Security Council Resolution (SC Res. 827, for the ICTR SC Res. 955) under Chapter VII of the UN Charter concerning "Action with Respect to Threats to the Peace, Breaches of the Peace, and Act of Aggression" in order

\footnotetext{
${ }^{19}$ Joyner, C., C., "Arresting Impunity: The Case for Universal Jurisdiction in Bringing War Criminals to Accountability". (1996) 59 LCP p. I7I.

\$) See. Prosecutor v. Slobodan Milosevic, Milan Milatinovic, Nikola Sainovic, Dragoljub Ojdanic and Vlajko Stojilkovic, Indictment, (22 May 1999). And also see, the Amended Indictment. Case No. IT-99-37-I. (29 June 200I).

${ }^{2}$ U.N.Doc. S/1995/999 (1995); reprinted in (1996) 35 ILM p. 89.; The representatives of the three Republics had initialied the General Framework Agreement for Peace in Bosnia and Herzegovina and the Annexes thereto on 21 November 1995 after the peace talks at Wright-Patterson Air Force in Dayton. Ohio.

"I Akhavan, P., "The Yugoslav Tribunal at a Crossroads: The Dayton Peace Agreement and Beyond". (1996) 18 HRQ p. 274.

${ }^{3}$ Hid.

"See silpra notes $3-4$
} 
to maintain the international peace and security. As is well-known, under Article 24 (1) of the UN Charter, the Security Council has "primary responsibility for the maintenance of international peace and security" and it acts on behalf of Member States. For discharging its duties. the Security Council has to act in accordance with the Purposes and Principles of the United Nations. Chapters VI, VII, VIII and XII give necessary power to the Security Council for the discharge of these duties..$^{25}$ Article 39 of the UN Charter. under Chapter VII, gives power to the Security Council to determine the existence of any threat to the peace and security, and to take necessary measures "in accordance with Article 41 and 42 to maintain or restore international peace and security". 26 Articles 41 and 42 of the Charter allow the Security Council to undertake actions in order to give effect to its decisions..$^{77}$ Lastly, so as to perform its functions, the Security Council can establish subsidiary organs, acting under the Charter of the United Nations. . $^{2 *}$ As a result of these legal regulations, the ICTY and the ICTR created by means of Security Council Resolutions can be seen as "a product of the combination of these powers." international institution by way of a Security Council Resolution under Chapter VIJ of the UN Charter lies on the fact that it imposes an obligation on all States of the UN to co-operate with the established organ. In the Yugoslavian case, all member States of the UN are under the obligation of bringing individuals responsible for international crimes to justice, in other

3 Article 24 (2) of the UN Charter. The Purposes and Principles of the United Nations are laid down in Chapter 1 of the UN Charter (Articles 1-2).

26 Article 39 of the UN Charter provides: "The Security Council shall determine the existence of aty threat to the peace. breach of the peace, or act of aggression and shall make recommendations, or decide what measures shall be taken in accordatice with Article 41 and 42, to maintain or testore international peace and security."

2? Article 41 of the UN Charter provides: "The Security Council may decide what measures not involving the use of armed force are to be employed to give effect to its decisions. ... These may include complete or partial interruption of economic relations and of rail. sea, arr. postál, telegraphic, radio and other means of communication, and the severance of diplomatic relations."

Article 42 of the UN Charter provides: "Should the Security Council that measures provided for in Article 41 would be inadequate or have proved to be inadequate. it may take such action by air, sea or land forces as may be necessary to maintain or restore international peace and security. Such action may include demonstrations, blockade, and oller operations by air. sea or Jand forces of Members of the United Nations."

"Article 29 of the UN Charter states: "The Security Council may establish such subsidiary organs as it decms necessary for the performance of its functions." Article 7 (2) of the UN Charter is also related to subsidiary organs.

${ }^{n}$ Bassiouni, M., C.. and Manikas, P. The Law of the Inernationat Criminat Tribumat for the Formes Yugestariatlrvington-on-Hudson. New York: Tratusnational Publishers. $1996)$. p. 239. 
words, to the ICTY. It is needless to say that it includes orders of arrest and of transfers of responsible individuals to the Court.

Lastly, in compliance with the way of establishment and of adoption of the ICTY Statute, all Member States of the United Nations are under the obligation to co-operate with the ICTY. Article 29 of the Statute of the ICTY, under the title of "cooperation and judicial assistance", reflects this fact and imposes an international obligation on all States to fully co-operate with the ICTY. Article 29 (1) provides: "1. States shall cooperate with the International Tribunal in the investigation and prosecution of persons accused of committing serious violations of international humanitarian law." Article 29 (2) then indicates such cooperation or assistance as follows: " 2 . States shall comply without undue delay with any request for assistance or an order issued by a Trial Chamber, including, but not limited to: (a) the identification and location of persons; (b) the taking of testimony and the production of evidence: (c) the service of documents: (d) the arrest or detention of persons: (e) the surrender or the transfer of the accused to the International Tribunal". Under these principles, it is clear enough that cooperation in surrendering or transferring of an accused person, in our case Slobodan Milosevic, to the ICTY is an international obligation of the Federal Republic of Yugoslavia. ${ }^{31}$

The aforementioned reasons explain the legal basis of the transfer of Slobodan Milosevic to the International Tribunal at the Hague. On the other hand, in addition to these facts, the moral reason should also be taken into account, that is to say that, the international community has to take decisive steps to prosecute and punish the individuals responsible for the odious crimes committed in different parts of the world, including the Yugoslavian case. ${ }^{32}$ In particular, the approach taken by the world community in the last decade of the twentieth century should be considered as violations of international human rights and humanitarian law will not be tolerated and accountable persons will not go unpunished. In terms of giving a clear signal to the possible responsible individuals of international crimes, the surrender of Slobodan Milosevic to the International Tribunal should be seen as a turning point in the enforcement of the rules of international humanitarian law.

\footnotetext{
${ }^{\text {it }}$ Scharf, M., "The Letter of the Law: The Scope of the International Legal Obligation to Prosecute Human Rights Crimes", (1996) 59 LCP p. 59.: McGoldrick. D., and Warbrick. C.. "International Criminal Law". (1995) 44 ICLQ p. 468.; Morris and Scharf, p. 42.; Morris and Scharf, the ICTR, p. 102.: Secretary-Gencral's Report. para. 23.

${ }^{31}$ Gallant, K., S., "Securing the Presence of Defendants before the International Tribunal for the Former Yugoslavia: Breaking with Extradition"., (1994) 5 CLF p. 562.

"Akhavan, P.. "Punishing War Crimes in the Former Yugoslavia: A Critical Juncture for the New World Order". (1993) I5 HRQ p. 289.
} 


\section{Was Slobodan Milosevic "Extradited" or "Transferred or Surrendered" to the ICTY}

The term "extradition" is used to describe the process "whereby onc sovereign surrenders to another sovereign a person sought after as an accused criminal or a fugitive offender". "The concept of extradition well established and developed a complex set of procedures and exceptions. As clearly inferred from the definition of extradition, it concerns relations. between two sovereign States. The law of extradition derives from treaties and agreements which are usually negotiated bilaterally by States, in accordance with the princjple of equality of States. Each treaty concerning the notion of extradition can contain different arrangements and exceptions. Some traditional exceptions to extradition can be indicated as follows: prohibitions on extradition of nationals, political, military and fiscal offence exceptions, dual criminality, tertitoriality, statutes of limitations and non bis in idem (a principle in criminal law that means a person shall not be tried twice for the same crime). In this context, using the term "traditional" in relation to extradition must not mislead the international community in the sense that they are traditional, but they are not part of customary international law. As far as international crimes such as genocide, war crimes. crimes against humanity and other serious violations of international humanitarian law are in question, these exceptions have no place to be applied in international law, and thus cannot constitute any principle of customary international law.

On the other hand, when the relationship between States and international criminal court or international criminal tribunals is examined, it can clearly be understood that it is a totally different and separate mechanism from the concept of extradition. This new relationship, which the international community has witnessed the first time by the establishment of the ICTY and the ICTR, should be named as "surrender or transfer" of suspicious persons to an international criminal court or tribunal. The main reasons for that can be indicated as follows:

Firstly, as just mentioned above, the law of extradition governs relations between two sovereign States and derives from treaties or agreements which

${ }^{33}$ Bassiouni. M.. C. Intemational Extradition and World Public Order, (1974), in Kenneth S. Gallant, "Sccuring the Presence of Defendants before the International Tribunal for the Former Yugoslavia: Breaking with Extradition". (1994) 5 CLF p. 558 .

${ }^{4}$ Bassiouni. M. C.. International Criminal Law: Procedure: (1986).: Bedi. S.. D., Extradition in Inernational Law and Practice. (1968).

"Armesty Intemational. "The Intemational Criminal Court. Making the Right ChoicesPart III. Ensuring Efrective State Cooperation", Al Index: IOR 40/13/97. (November 1997). (hereinalter Ambers Intemitional Report). p. 39. 
are negotiated in compliance with the principle of equality of States. It establishes a horizontal relationship in nature. However, the relationship between States and an international judicial body should not be considered as extradition on the ground that surrendering or transferring a suspicious person to an international criminal court or tribunal is an international obligation that is superior to any national law that might prevent surrender or transfer either generally or individual cases. In other words, the authority of international body binds all States and therefore, it creates a vertical relationship in character. ${ }^{36}$ Actually, it was the case which the international community has seen its application in the practice of the ICTY and the ICTR. According to the Statute of the ICTY, all States are under the obligation to surrender or transfer any accused person to the Tribunal when it is requested (Article 29). This is also one of the results of the establishment of the ad hoc Tribunal through the UN Resolution 827 (1993) in accordance with Chapter VII of the UN Charter. The ICTY's requests for surrender or transfer override any domestic law that might prevent surrender or transfer. In this sense, the provisions of Article 58 of the Rules of Procedure and Evidence should be noted: Rule 58 in compliance with Article 29 provides that the obligations of States "shall prevail over any legal impediment to the surrender or transfer of the accused or of a witness to the ICTY which may exist under the national law or extradition treaties of the State concerned".

Secondly, as has been inferred from the above mentioned principles, the traditional exceptions, such as prohibitions on extradition of nationals, political, military and fiscal offence exceptions, to extradition are not relevant to the transfer or surrender of an accused person to the International Criminal Tribunal. ${ }^{37}$ Non-application of the traditional exceptions of the law of extradition to the concept of transfer or surrender is so important in terms of enforcing the rules of international humanitarian law. This is because, the core crimes of genocide, war crimes, crimes against humanity and other serious violations of international humanitarian law have been committed or facilitated by persons working on behalf of State policy, or in the name of State policy. Without such a State oriented support, these crimes would not have been perpetrated. If the traditional exceptions to extradition had been applied to the notion of transfer or surrender it would not have been possible to try many accused individuals charged with international crimes

\footnotetext{
${ }^{36}$ Cassese. A., "On the Current Trends towards Criminal Prosecution and Punishment of B reaches of International Humanitarian Law", (1998) 9 EJIL p. 13.; Gallant. p. 562.

${ }^{37}$ For the reasons, see Amnesty International Report, pp. 41-47.: Fox. H.. "The Objections to Transfer of Criminal Jurisdiction to the UN Tribunal", (1997) 46 ICLQ pp. 436437.; For the US practice, see Kushen, R., and Harris, K.J." "Surrender of Fugitives by the United States to the War Crimes Tribunals for Yugoslavia and Rwanda", (1996) $90 \mathrm{AJIL} \mathrm{pp}$. $510-518$.
} 
committed in the former Yugoslavia and in Rwanda on the ground that those responsible have the nationality of mentioned States that constitute one of the fundamental exception of the extradition law. ${ }^{3 .}$

Thirdly, the practice of the international community also supports the fact that extradition to a State and transfer or surrender to an international jurisdiction are totally different concepts: UN Security Council Resolution 827 (1993), the ICTY's Statute and the Secretary-General's Report do nol deploy the word "extyadition", instead, the terms "surrender or transfer" are used in the mentioned international law documents. ${ }^{39}$ It is worth noting here that Articles 86 under the heading of "General obligation to cooperate" and 89 under the heading of "Surrender of persons to the Court" of the ICC Statute do not use the word "extradition", but "surrender". The ICC Statute should be considered as the most authoritative international humanitarian law instrument reflecting the customary law rules and the practice of the international community as well. It is also so significant in the sense that it clarifies the existing law rules and makes clear that the concept of extradition is different from the transfer or surrender of a person to an international judicial body. In this sense, it should also be noted that the mechanisms at the international level are different from the mechanisms which we know from the domestic law practice. Extradition may be sufficient at the national law level, but not at the international level.

For the aforementioned reasons, the handing over of Slobodan Milosevic to the ICTY at the Hague must be named as transfer or surrencler of him to the International Tribunal, not as an extradition. This fact also constitutes a perfect example which indicates the application of rules in the international criminal justice system is quite different from its clomestic counterpart.

\section{Conclusions}

The arrest and transfer of Slobodan Milosevic to the ICTY constitute a landmatk development in international humanitarian law. It clearly indicates one of the biggest decisive steps of the international community in terms of reflecting the desire of the world community to enforce the rules of international law. The practice of the ICTY and the ICTR and also the adoption of the ICC Statute have proved the enforceability of the principle of individual criminal responsibility for those who committed or facilitated the commission of international crimes regardless of their positions, whether

\footnotetext{
${ }^{27}$ Gallant. p. 570.

${ }^{34}$ In particular. see Articles 28 and 29 of the Statutes of the ICTR and the ICTY respectively.
} 
as Head of State or Government or other senior government officials or just ordinary soldiers. The approach taken by the international community should be considered as serious violations of international human rights and humanitarian law will not be tolerated and accountable persons will not go unpunished. The Milosevic case is only the beginning of this development and it gives a clear signal to the possible responsible individuals of international crimes.

Additionally, the transfer of Milosevic to the ICTY has another significance in terms of indicating the differences between the concepts of "extradition" and "transfer or surrender" to an international judicial body in international law. The latest developments and the practice of the ad hoc tribunals prove that the law of extradition is not applicable at the international level. The notion of transfer or surrender of accused persons to an international criminal court or tribunal should be regarded as a sine qua non element in order to enforce the principles of international humanitarian law. 